\title{
Screening of lentil genotypes for resistance to Bean yellow mosaic virus and effect of mixed infection on the susceptibility of some resistant lentil genotypes
}

\author{
Aya Kanawaty ${ }^{1,3}$, Safaa G. Kumari ${ }^{1}$, Joop van Leur ${ }^{2}$ and Hassan Hammadi ${ }^{3}$ \\ (1) International Center for Agriculture Research in the Dry Areas (ICARDA), Aleppo, Syria (Present address: ICARDA, \\ P.O. Box 114/5055, Postal Code: 1108-2010, Beirut, Lebanon), Email: s.kumari@cgiar.org; \\ (2) New South Wales Department of Primary Industries (NSW DPI), Tamworth, Australia; \\ (3) Department of Botany, Faculty of Science, Aleppo University, Aleppo, Syria.
}

\begin{abstract}
Kanawaty, A., S.G. Kumari, J. van Leur and H. Hammadi. 2017. Screening of lentil genotypes for resistance to Bean yellow mosaic virus and effect of mixed infection on the susceptibility of some resistant lentil genotypes. Arab Journal of Plant Protection, 35(3): 171-177.

A total of 100 lentil genotypes were evaluated for their reaction to a Syrian isolate (SV205-85) of Bean yellow mosaic virus (BYMV, genus Potyvirus, family Potyviridae) under field conditions during 2010/2011 growing season. All plants were inoculated mechanically before flowering stage and selection of resistance was based on: (i) visual symptoms incidence and severity, and (ii) virus movement in the plant tissues based on tissue-blot immunoassay (TBIA) test. Only one genotype (ILL1949) was highly resistant to BYMV and another three (ILL518, ILL1935 and ILL7470) were found resistant. Sixteen lentil genotypes with different levels of susceptibility to BYMV were selected to study the effect of mixed virus infection of BYMV and Faba bean necrotic yellows virus (FBNYV, genus Nanovirus, family Nanoviridae) under plastic house conditions. All plants studied were inoculated mechanically with BYMV followed by FBNYV using viruliferous pea aphids (Acyrthosiphon pisum Harris), and were tested 28 days after inoculation by TBIA. Serological results showed that inoculation with FBNYV did not alter the resistance to BYMV of two lentil resistant genotypes (ILL518 and ILL5005), whereas inoculation with FBNYV increased the susceptibility to BYMV in three lentil genotypes (ILL336, ILL4736 and ILL1949). Three genotypes (ILL74, ILL75 and ILL213) were found highly resistant to BYMV and FBNYV with single virus infection and became moderately resistant to BYMV and resistant to FBNYV following mixed virus infection.

Keywords: BYMV, FBNYV, TBIA, single infection, mixed infection
\end{abstract}

\section{Introduction}

Lentil (Lens culinaris Medik.) crop is an important food crop and is considered as one of the main protein sources for a large part of the population in West Asia and North Africa (WANA) region. Viral diseases are among the factors causing yield losses in lentil. Eighteen viruses are reported to infect lentils $(13,26)$, but only few of them are widespread and cause significant economic damage.

Bean yellow mosaic virus (BYMV, genus Potyvirus, family Potyviridae) naturally infects a wide range of legume species including lentil as well as some non-legumes (13). The virus is transmitted in a non-persistent manner by many aphid species or, under experimental conditions, by mechanical inoculation (2). The characteristic symptoms of BYMV on lentil are chlorosis, mild mosaic or mottling, and stunting. Leaves often become twisted or curled with necrosis along the margins. Flowering and pod formation is reduced as a result of infection and consequently little seed is produced (12).

Faba bean necrotic yellows virus (FBNYV, genus Nanovirus, family Nanoviridae) naturally infects legume crops in most of WANA countries, especially faba bean, lentil and chickpea $(9,11,13)$. FBNYV is persistently transmitted only by aphid species (e.g. Acyrthosiphon pisum Harris and Aphis craccivora Koch.) (4).
Although plant viruses can be controlled through several methods, development of resistant genotypes is the most effective and economic approach. The use of resistant cultivars in an integrated disease management strategy is essential, especially where and when crop hygienic cultural practices are difficult to implement. In fact resistance to disease, including virus diseases, is one of the major objectives in cool season legume breeding programs. So far only a limited number of lentil genotypes were identified with resistance to BYMV and FBNYV $(18,19)$.

Mixed infections of plant viruses are common in nature. Interactions between viruses in plants are common, and some viruses depend on such interactions for their survival. An interaction between two viruses can be synergistic or antagonistic, complete or partial, and bilateral or unilateral. The interaction may be complete or partial, e.g., infection by one virus may completely prevent or merely reduce infection by another virus $(3,7,8,20,21,25,28)$. However, until now no information is available on the effects of mixed viral infections on lentils.

The aim of this study is to identify resistant lentil genotypes to a Syrian isolate of BYMV, and to assess the effects of FBNYV infection on susceptibility of resistant lentil genotypes to infection with BYMV under plastic house conditions.

http://dx.doi.org/10.22268/AJPP-035.3.171177

(C) 2017 Arab Society for Plant Protection الجمعية العربية لوقاية النبات 


\section{Materials and methods}

\section{Field Screening}

Lentil genotypes- A total of 100 lentil genotypes originated from 33 countries and are available as part of the collection held in the Gene Bank of ICARDA (Table 1) were evaluated for their reaction to a Syrian isolate of BYMV.

BYMV isolate and mechanical inoculation-The BYMV virus isolate SV205-85 used in this study was previously collected from a faba bean (Vicia faba L.) plant in TelHadya, Aleppo, Syria, and identified earlier as BYMV (17). This isolate was maintained on faba bean "Syrian Local" (ILB 1814) by serial mechanical inoculation under glass house conditions. The inoculum for artificial mechanical inoculation was prepared by grinding BYMV-infected faba bean tissue in $0.01 \mathrm{M}$ potassium phosphate buffer, $\mathrm{pH} 7.2$ $(1: 10, \mathrm{~W} / \mathrm{V})$ and mixed with $0.5 \%$ Celite and $0.5 \%$ sodium sulphite as antioxidant (W/V). All tested plants were inoculated mechanically with a sprayer using an air compressor that supplied a constant pressure of 9 bar. After that, inoculated plants were washed with water immediately after inoculation and sprayed with an insecticide (Thiamethoxam) at $1 \mathrm{~g} /$ litter.

Screening for resistance trials-Lentil genotypes were planted following a Randomized Complete Block design in 2 replicates for both the inoculated and non-inoculated treatments at ICARDA station, south of Aleppo, in northern Syria under rain-fed conditions during 2010/2011 growing season. Each genotype was planted in one $1.5-\mathrm{m}$ row (30 seeds/row)/replicate with $70 \mathrm{~cm}$ between rows. Both inoculated and non-inoculated treatments were maintained virus-free by regular sprays of Thiamethoxam (1 g/litter) once every 20-25 days for the duration of the experiment. Ten weeks after planting, all lentil plants were inoculated mechanically under pressure using a compressor as described previously. Faba bean (Syrian local, ILB1814) was planted as a susceptible marker between every 10 lentil genotypes to determine the success of inoculation. Visual readings of incidence and severity of infection based on the characteristic symptoms of BYMV (mosaic/mottling, necrosis, stunting, reddening) was made 4 weeks after inoculation. Disease score (DS) was based on a $0-3$ scale $(0=$ no symptoms, $3=$ severe symptoms) and recorded for each genotype. In addition, five weeks after inoculation, all inoculated plants were tested by tissue-blot immunoassay (TBIA) (16) using BYMV-specific polyclonal antibody produced against SV205-85 isolate at ICARDA's virology laboratory for the presence of BYMV, and percent of infected plants was determined for each genotype.

Effect of mixed infection on susceptibility of lentil genotypes under plastic conditions

Lentil genotypes - Nine lentil genotypes with different levels of BYMV resistance were selected based on the field screening conducted during 2010/2011 growing season
(Table 2). In addition, two lentil genotypes (ILL336 and ILL4736) resistant to BYMV (1), four lentil genotypes (ILL74, ILL75, ILL85, ILL213) resistant to three viruses [FBNYV, Bean leafroll virus (BLRV, genus Luteovirus, family Luteoviridae) and Soybean dwarf virus (SbDV, genus Luteovirus, family Luteoviridae) (18) and one lentil "Syrian local variety" (ILL4400) were used (Table 2).

Table 1. Origin of lentil genotypes evaluated for Bean yellow mosaic virus (BYMV) resistance during 2010/2011 growing season under field conditions.

\begin{tabular}{|c|c|c|}
\hline Lentil genotypes (ILL) & $\begin{array}{c}\text { No. of } \\
\text { genotypes }\end{array}$ & Origin \\
\hline ILL83, 1762, 1766, 1786, 5520 & 5 & Argentina \\
\hline ILL6110 & 1 & Armenia \\
\hline ILL86 & 1 & Azerbaijan \\
\hline ILL6112, 6117 & 2 & Azerbaijan \\
\hline ILL361, 1830, 1843, 4560, 4592 & 5 & Chile \\
\hline ILL210 & 1 & Costa Rica \\
\hline ILL5971, 5974, 5977, 5979 & 4 & Cyprus \\
\hline ILL7053, 7480, 7481 & 3 & Algeria \\
\hline ILL4920 & 1 & Egypt \\
\hline ILL80, 4950, 5005, 5034, 5473 & 5 & Spain \\
\hline $\begin{array}{l}\text { ILL1673, 1734, 2134, 5889, } \\
\quad 5928\end{array}$ & 5 & Ethiopia \\
\hline ILL299, 312, 4845, 4866, 4868 & 5 & Greece \\
\hline ILL220, 518, 2524, 3635, 5072 & 5 & India \\
\hline ILL1437, 4903, 6418 & 3 & Iran \\
\hline ILL53, 4370 & 2 & Iraq \\
\hline ILL341, 5478 & 2 & Italy \\
\hline $\begin{array}{l}\text { ILL1884, 5176, 5291, 5319, } \\
\quad 6925\end{array}$ & 5 & Jordan \\
\hline ILL849, 852 & 2 & Lebanon \\
\hline $\begin{array}{l}\text { ILL4800, 6492, 7623, 7595, } \\
\quad 7736\end{array}$ & 5 & Morocco \\
\hline ILL498 & 1 & Mexico \\
\hline ILL622, 1935 & 2 & Macedonia \\
\hline ILL1933 & 1 & Montenegro \\
\hline $\begin{array}{l}\text { ILL4610, 7224, 7293, 7344, } \\
\quad 7470\end{array}$ & 5 & Nepal \\
\hline ILL230, 6065, 6098, 6338, 7645 & 5 & Pakistan \\
\hline ILL338 & 1 & Peru \\
\hline ILL4792 & 1 & Russia \\
\hline ILL7743 & 1 & Saudi Arabia \\
\hline ILL5505 & 1 & Sudan \\
\hline ILL1949 & 1 & Serbia \\
\hline $\begin{array}{l}\text { ILL34, 5568, 6524, 6697, 6852, } \\
\quad 7069\end{array}$ & 6 & Syria \\
\hline $\begin{array}{c}\text { ILL118, 136, 326, 566, 645, } \\
1873,4352,6155,7081\end{array}$ & 9 & Turkey \\
\hline ILL1600 & 1 & USA \\
\hline ILL4749, 4752, 4754 & 3 & Yemen \\
\hline Total & 100 & \\
\hline
\end{tabular}

FBNYV isolate and aphid inoculation - The FBNYV virus isolate used in this study (SV66-95) was collected from a faba bean plant in Lattakia, Syria (10) and maintained on faba bean "Syrian local" (ILB1814) by serial transfer using the aphid vector $A$. pisum.

A pure colony of $A$. pisum collected from pea (Pisum sativum L.) in Lattakia, Syria was established from a single apterous aphid, and was reared in screen cages in a glasshouse at ICARDA. Aphids were kept on FBNYV- 
infected plants for $48 \mathrm{hr}$, in order to acquire the virus; $10-15$ viruliferous $A$. pisum were then placed on each plant to be inoculated and a small plastic cage was placed on each pot. The aphids were allowed to feed on the tested plants for 48 $\mathrm{hr}$, after which they were killed with an insecticide (Thiamethoxam at $1 \mathrm{~g} /$ litter).

Experimental design and evaluation -The experiment was conducted in a plastic house, at a temperature of $18-20^{\circ} \mathrm{C}$, during February and March, 2012 at Tel-Hadya, Aleppo, Syria. Forty-five seeds of each genotype were sown in plastic pots $(25 \mathrm{~cm}$ in diameter; 5 seeds/ pot) by using Randomized Complete Block design with 3 replicates. Twelve days after planting, all plants were inoculated in the same day as follows: (i) three pots were inoculated mechanically as described previously with BYMV only, (ii) three pots were inoculated with FBNYV only using viruliferous $A$. pisum, and (iii) three pots were inoculated mechanically first with BYMV followed by FBNYV using viruliferous aphids.

To study the \% of infection and systemic movement of BYMV and FBNYV, all inoculated plants were tested 28 days after inoculation by TBIA using BYMV-specific polyclonal antibody (SV205-85) and FBNYV-specific monoclonal antibody (2E9) (5) for the presence of BYMV and FBNYV. Percent of infected plants with each virus was determined for each genotype.

\section{Results}

Screening of lentil genotypes under field conditions When 100 lentil genotypes were evaluated for their reaction to a Syrian isolate of BYMV under field conditions, it was evident that many of them were not uniform in their reaction to the virus. On the basis of symptoms produced, it was easy to differentiate between severe, mild and symptomless plants (Figure 1). The common disease symptoms observed in lentil genotypes for infection with BYMV were yellowing, stunting and necrosis. Some genotypes showed leaf reddening. Disease score (DS) and \% of infection of tested genotypes are summarized in Table 3.

Based on disease score (DS) and \% of infection, it was possible to divide the genotypes into four categories: (I) Highly resistant: genotypes which did not produce symptoms $(\mathrm{DS}=0)$ and \% of infection based on serological test was less than 10\% (only one genotype, ILL1949); (II) Resistant: genotypes with DS $=1$ and $\%$ infection of $25 \%$ or less (only three genotypes: ILL518, ILL1935, ILL7470); (III) Moderately resistant: genotypes with $\mathrm{DS}=2$ and \% infection was $50 \%$ or less (such as ILL83, ILL1437, ILL1766, ILL1786, ILL1933), and (IV) Susceptible: genotypes with $\mathrm{DS}=3$ and $\%$ infection higher than $50 \%$ (100\% with some genotypes; e.g. ILL849, ILL5977, ILL6852, ILL7743) (Table 3).

Effect of mixed infection on susceptibility of lentil genotypes under plastic house conditions

A considerable variation was observed for disease reaction among lentil genotypes between single and mixed virus infection and the response to mixed infection in some cases was severe.
Based on TBIA results 28 days after inoculation, the following different reaction types were observed: (i) genotypes highly resistant to BYMV either in single or mixed virus infection, but were susceptible to FBNYV infection (ILL518 and ILL5005); (ii) genotypes highly resistant to FBNYV either in single or mixed infection, but were resistant to BYMV infection (ILL74 and ILL213), (iii) genotypes highly resistant to BYMV in single virus infection and were moderately resistant to BYMV in mixed infection with FBNYV (such as ILL336, ILL1949, ILL4736); (iv) genotypes highly resistant to FBNYV and BYMV in single virus infection and were moderately resistant to both viruses in mixed infection (only one genotype, ILL75) (Table 4).

The results obtained following data analysis using ANOVA (Analysis of Variance) showed that there was significant difference and obvious effect of FBNYV on the response of BYMV in mixed infection (means of BYMV= $12.8 \%$, and $\mathrm{BYMV}+\mathrm{FBNYV}=24.3 \%$, note that $\mathrm{LSD}=$ $7.7 \%$ ). Whereas, the adverse impact for BYMV on FBNYV reaction in mixed infection was not significant and the main effects of FBNYV response depends only on the genotypes (means of $\mathrm{FBNYV}=40.6 \%$, and $\mathrm{BYMV}+\mathrm{FBNYV}=45.1 \%$, note that $\mathrm{LSD}=10.8 \%$ ).

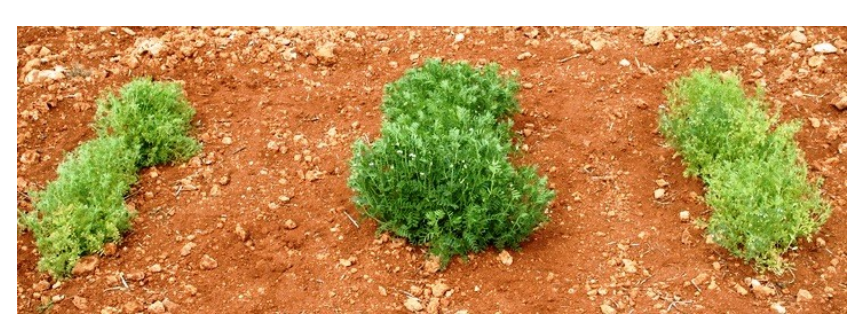

Figure 1. Reaction of resistant (ILL1949-middle) and susceptible (ILL1873-left and ILL5568-right) lentil genotypes to infection with Bean yellow mosaic virus (BYMV) under field conditions.

\section{Discussion}

When lentil pure lines from ICARDA's Genebank were evaluated for their reaction to BYMV infection under field conditions, it was evident that many of them were not homogeneous for BYMV resistance. On the basis of symptoms produced, it was easy to differentiate between severe, mild, and symptomless plants. Among symptomless plants, and by using TBIA, it was possible to differentiate between symptomless resistant plants(such as ILL518, ILL1935, ILL1949 and ILL7470) and symptomless infected plants (such as ILL1933), as some genotypes in our study could have latent infection as described in Figure 1 for ILL5568 which had a disease score of 1.1-2.0 and 75-90\% virus infection. Most of the highly susceptible genotypes with $100 \%$ infection died or gave a limited amount of seeds. Such lentil heterogeneity in response to BYMV infection has been reported earlier (1). In view of the apparent heterogeneity of most tested accessions it would be desirable to repeat these trials with genetically pure single plant progenies in order to differentiate between complete and partial resistance. 
Table 2. Performance of the selected lentil genotypes for Bean yellow mosaic virus (BYMV) during 201/2011 growing season under field conditions, which used in single and mixed infection with Faba bean necrotic yellows virus (FBNYV) under plastic house conditions.

\begin{tabular}{|c|c|c|c|c|c|}
\hline \multirow[b]{2}{*}{$\begin{array}{l}\text { Lentil } \\
\text { genotype }\end{array}$} & \multirow[b]{2}{*}{ Origin } & \multicolumn{3}{|c|}{$\begin{array}{l}\text { Reaction with BYMV under field condition during 2010/2011 } \\
\text { growing season }\end{array}$} & \multirow[b]{2}{*}{ Source/reference } \\
\hline & & $\begin{array}{c}\text { \% of infection } \\
\text { with BYMV based } \\
\text { on serological } \\
\text { (TBIA) test } \\
\end{array}$ & $\begin{array}{c}\text { Disease Score } \\
(0-3)^{\mathrm{a}}\end{array}$ & Type of symptoms & \\
\hline \multicolumn{6}{|c|}{ Genotypes selected from this study } \\
\hline ILL83 & Afghanistan & 35.1 & 1.0 & Yellowing & This study \\
\hline ILL299 & Greece & 78.7 & 2.0 & Yellowing & This study \\
\hline ILL518 & India & 5.0 & 0.5 & Yellowing & This study \\
\hline ILLL1600 & USA & 83.3 & 2.0 & Yellowing & This study \\
\hline ILL1884 & Jordan & 96.4 & 3.0 & Yellowing & This study \\
\hline ILL1933 & Montenegro & 36.4 & 0.0 & No symptoms & This study \\
\hline ILL1949 & Serbia & 7.1 & 0.0 & No symptoms & This study \\
\hline ILL4845 & Greece & 92.1 & 2.5 & Yellowing + Reddening & This study \\
\hline ILL5005 & Spain & 5.8 & 0.5 & No symptoms & This study \\
\hline \multicolumn{6}{|c|}{ Genotypes selected from previous studies } \\
\hline ILL336 & France & \multicolumn{3}{|l|}{ Resistant to BYMV } & Alkhalaf (1) \\
\hline ILL4736 & Canada & \multicolumn{3}{|l|}{ Resistant to BYMV } & Alkhalaf (1) \\
\hline ILL74 & Chile & \multicolumn{3}{|c|}{ Resistant to FBNYV, BLRV, SbDV $\mathbf{b}$} & Makkouk et al. (18) \\
\hline ILL75 & Chile & \multicolumn{3}{|c|}{ Resistant to FBNYV, BLRV, SbDV } & Makkouk et al. (18) \\
\hline ILL85 & Tajikistan & \multicolumn{3}{|c|}{ Resistant to FBNYV, BLRV } & Makkouk et al. (18) \\
\hline ILL213 & Afghanistan & \multicolumn{3}{|c|}{ Resistant to FBNYV, BLRV } & Makkouk et al. (18) \\
\hline ILL4400 & Syria & \multicolumn{4}{|c|}{ Syrian Local (Large seeds) - used as a control } \\
\hline
\end{tabular}

Table 3. Disease score (DS) and \% of infection categories ${ }^{a}$ of lentil genotypes inoculated with Bean yellow mosaic virus (BYMV) under field condition during 2010/2011 growing season.

\begin{tabular}{|c|c|}
\hline Lentil genotypes $^{b}$ & $\begin{array}{c}\text { \% of infection with BYMV based on } \\
\text { serological (TBIA) test }\end{array}$ \\
\hline ILL518, $-1949,-5005$ & Less than $10 \%$ \\
\hline ILL1935, -7470 & $11.1-25$ \\
\hline ILL83, $-1437,-1766,-1786,-1933,-4560,-7293$ & 25.1-50 \\
\hline ILL136, $-210,-312,-341,-1673,-1762,-3635,-4749,-4752,-6098,-6338,-7053,-7344$ & $50.1-75$ \\
\hline ILL34, $-53,-80,-86,-118,-220,-230,-299,-326,-338,-361,-498,-566,-622,-645,-1600,-$ & $75.1-90$ \\
\hline $1734,-1830,-1873,-1884,-2134,-2524,-4352,-4370,-4592,-4610,-4754,-4792,-4800,-4845$ & \\
\hline$-4866,-4868,-4903,-4920,-4950,-5034,-5176,-5291,-5319,-5478,-5505,-5520,-5568,-5889$ & \\
\hline$-5928,-5971,-5974,-5979,-6110,-6112,-6155,-6492,-6524,-6697,-6925,-7069,-7081,-7480$ & \\
\hline$-7481,-7595,-7623,-7645,-7736$ & \\
\hline \multirow[t]{2}{*}{ ILL849, $-852,-1843,-5072,-5473,-5977,-6065,-6117,-6418,-6852,-7224,-7743$} & 100 \\
\hline & Disease Score (0-3) categories ${ }^{c}$ \\
\hline ILL1786, -1933, -1935, -1949 & 0 \\
\hline ILL83, $-518,-1437,-1766,-5005,-7293,-7470$ & $0.1-1$ \\
\hline ILL34, $-86,-136,-210,-299,-312,-338,-341,-852,-1600,-1673,-1734,-1762,-1873,-3635,-$ & $1.1-2$ \\
\hline $4352,-4560,-4749,-4752,-4792,-4868,-4950,-5034,-5176,-5505,-5568,-5889,-5974,-6098$ & \\
\hline$-6110,-6112,-6117,-6155,-6492,-6697,-7053,-7344,-7481,-7645$ & \\
\hline ILL53, $-80,-118,-220,-230,-326,-361,-498,-566,-622,-645,-849,-1830,-1843,-1884,-2134$, & 2.1-3 \\
\hline$-2524,-4370,-4592,-4610,-4754,-4800,-4845,-4866,-4903,-4920,-5072,-5291,-5319,-5473$ & \\
\hline$-5478,-5520,-5928,-5971,-5977,-5979,-6065,-6338,-6418,-6524,-6852,-6925,-7069,-7081$ & \\
\hline$-7224,-7480,-7595,-7623,-7736,-7743$ & \\
\hline \multicolumn{2}{|c|}{$\%$ of seed germination was less than 25\% (average of two replicates) in ILL852, ILL6418, ILL5072, ILL7344. } \\
\hline \multicolumn{2}{|l|}{$\%$ of infection and symptoms score (mean of two replicates) per $1.5-\mathrm{m}$ row/replicate. } \\
\hline \multicolumn{2}{|c|}{ Disease score is based on symptoms severity of BYMV (mosaic/mottling, necrosis, stunting, reddening), using $0-3$ score (where $0=$ no } \\
\hline
\end{tabular}


Table 4. Bean yellow mosaic virus (BYMV) and Faba bean necrotic yellows virus (FBNYV) detection in lentil plants 28 days after inoculation with single virus and mixed with two viruses under plastic house conditions during 2012.

\begin{tabular}{|c|c|c|c|c|c|}
\hline \multirow{3}{*}{$\begin{array}{l}\text { Lentil } \\
\text { genotype }\end{array}$} & \multicolumn{5}{|c|}{$\%$ of plants infected ( 28 days after virus inoculation based on TBIA test) } \\
\hline & \multicolumn{2}{|c|}{ Single virus inoculation } & \multicolumn{3}{|c|}{ Mixed viruses inoculation } \\
\hline & BYMV & FBNYV & BYMV & FBNYV & BYMV+FBNYV \\
\hline ILL74 & 0 & 0 & 20 & 0 & 0 \\
\hline ILL75 & 0 & 0 & 20 & 10 & 10 \\
\hline ILL83 & 60 & 14 & 25 & 50 & 25 \\
\hline ILL85 & 0 & 13 & 20 & 40 & 0 \\
\hline ILL213 & 0 & 0 & 11 & 0 & 0 \\
\hline ILL299 & 44 & 78 & 70 & 70 & 50 \\
\hline ILL336 & 0 & 80 & 13 & 50 & 0 \\
\hline ILL518 & 0 & 40 & 0 & 50 & 0 \\
\hline ILL1600 & 10 & 56 & 43 & 57 & 43 \\
\hline ILL1884 & 20 & 67 & 44 & 33 & 22 \\
\hline ILL1933 & 0 & 22 & 10 & 80 & 0 \\
\hline ILL1949 & 0 & 60 & 11 & 55 & 11 \\
\hline ILL4400 & 38 & 70 & 66 & 55 & 44 \\
\hline ILL4736 & 0 & 78 & 10 & 50 & 10 \\
\hline ILL4845 & 25 & 33 & 14 & 71 & 14 \\
\hline ILL5005 & 0 & 78 & 0 & 70 & 0 \\
\hline
\end{tabular}

The plastic house experiments showed that inoculation with FBNYV did not affect the resistance level to BYMV of two lentil genotypes (ILL518 and ILL5005), whereas inoculation with FBNYV affected BYMV resistance in 8lentil genotypes (ILL74, ILL75, ILL85, ILL213, ILL336, ILL1933, ILL1949, ILL4736). In addition, results also showed that three lentil genotypes (ILL74, ILL75 and ILL213) were highly resistant to BYMV and FBNYV in response to single virus infection. Whereas, two of them (ILL74 and ILL213) became moderately resistant to BYMV only and one genotype (ILL75) became moderately resistant to BYMV and FBNYV in mixed virus infection. Makkouk et al. (18) found in a previous study that the above three genotypes (ILL74, ILL75, ILL213) were resistant to both FBNYV and BLRV. Accordingly, these genotypes can be recommended to lentil breeders as sources for virus resistance (BLRV, FBNYV and BYMV).

The interactions and effects of mixed infection in our study can be divided into three categories: (i) synergistic interaction which means that the incidence of the two viruses increased (such as ILL75, ILL85, ILL1933); (ii) unilateral antagonistic interaction (such as ILL1884) where the \% of BYMV infection increased compared with that of FBNYV which decreased; (iii) variable antagonistic interaction, where one virus maintained its percentage infection while the second virus either increased, decreased or kept its infection level unchanged (such as ILL74, ILL213, LL 518, ILL5005). Such type of interactions has been reported previously by Zhang et al. (30) in a range of virus pathosystems.

Response of plants to the synergistic action of two unrelated viruses has been studied earlier $(3,7,20,25)$. It has been generally assumed that the increased severity of symptoms is correlated with an increase in the concentration of at least one of the viruses in the mixture. Results of this study revealed that the \% of infection either with BYMV or FBNYV in lentil plants doubly infected was significantly higher than that in single infected plants; and the enhancement of BYMV and FBNYV infection was detected in double infected plants in 12 and 9 lentil genotypes, respectively, out of 16 lentil genotypes tested. It is common to observe an increase in accumulation of one or both viruses in the mixed infection relative to each virus alone $(3,7,23$, 29).

Most attention in virology research had traditionally been given to properties of individual virus species, whereas less attention has been paid to within-host interactions between viruses or between viruses and microorganisms in multiple infections $(14,24)$. Therefore, in this study we tried to shed light on the interaction between BYMV and FBNYV and the effects of mixed infection on susceptibility of lentil genotypes used, especially to viruses in the Potyvirus genus, whose transmission is known to depend on a helpercomponent protein $(6,15,22,27)$. In addition, there is a need to intensify efforts at continuously monitoring the predominant field virus strains, and develop advanced lentil breeding lines with multiple resistance to the economically important viruses. The seeds of such resistant genotypes should possess horticultural and culinary desirable traits, and should be readily available to growers, in order to minimize losses due to viral infections.

\section{Acknowledgment}

The financial support of the Grains Research and Development Corporation (GRDC), Australia, is highly appreciated. 


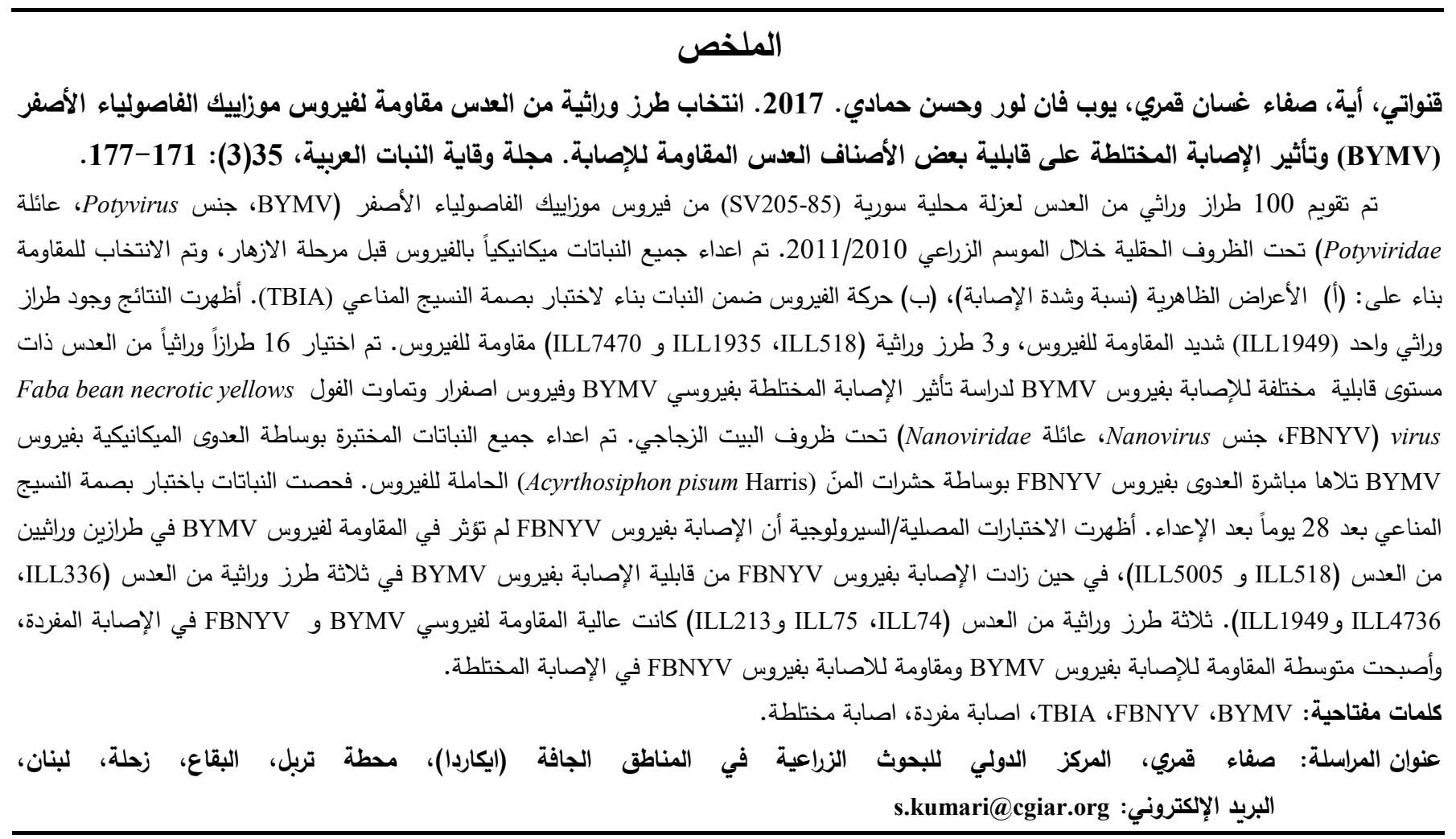

\section{References}

1. Alkhalaf, M. 2009. Bean yellow mosaic virus on coolseason food legumes and its control in Syria. PhD thesis. Department of Plant Protection, Faculty of Agriculture, Aleppo University, Aleppo, Syria, 114 pp.

2. Bos, L. 1970. Bean yellow mosaic virus. CMI/AAB Descriptions of Plant Viruses, 40, 4 pp.

3. Calvert, L.A. and S.A. Ghabrial. 1983. Enhancement by Soybean mosaic virus of Bean pod mottle virus titer in doubly infected soybean. Phytopathology, 73: 992997.

4. Franz, A., K.M. Makkouk and H.J. Vetten. 1998. Acquisition, retention and transmission of faba bean necrotic yellows virus by two of its aphid vectors, Aphis craccivora (Koch.) and Acyrthosiphon pisum (Harris). Journal of Phytopathology, 146: 347-355.

5. Franz, A., K.M. Makkouk, L. Katul and H.J. Vetten. 1996. Monoclonal antibodies for the detection and differentiation of faba bean necrotic yellows virus isolates. Annals of Applied Biology, 128: 255-268.

6. Froissart, R., Y. Michalakis and S. Blanc. 2002. Helper component-trans complementation in the vector transmission of plant viruses. Phytopathology, 92: 576-579.

7. Goldberg, K. and K.M. Brakke. 1987. Concentration of Maize chlorotic mottle virus increased in mixed infections with maize dwarf mosaic virus, strain B. Phytopathology, 77: 162-167.

8. Kassanis, B. 1963. Interaction of viruses in plants. Advances in Virus Research, 10: 219-255.
9. Kumar, P.L., S.G. Kumari and F. Waliyar. 2008. Virus diseases of chickpea. Pages 213-234. In: Characterization, Diagnosis and Management of Plant Viruses: Vol 3. Vegetable and Pulse Crops, G.P. Rao, P.L. Kumar and R.J.H. Penna (eds.), Studium Press LLC, Texas, USA.

10. Kumari, S.G. 2002. A study on luteoviruses affecting cool-season food legumes. PhD thesis. Department of Plant Protection, Faculty of Agriculture, Aleppo University, Aleppo, Syria, 230 pp.

11. Kumari, S.G. and K.M. Makkouk. 2007. Virus diseases of faba bean (Vicia faba L.) in Asia and Africa. Plant Viruses, 1: 93-105.

12. Kumari, S.G., K.M. Makkouk and I.D. Ismail. 1994. Seed transmission and yield loss induced in lentil (Lens culinaris Med.) by bean yellow mosaic potyvirus. LENS Newsletter, 21: 42-44.

13. Kumari, S., R. Larsen, K.M. Makkouk and M. Bashir. 2009. Virus Diseases and their Control. Pages 306-325. In: The Lentil Botany, Production and Uses. W. Erskine, F.J. Muchlbauer, A. Sarker and B. Sharma (eds.). CAB International.

14. Lidsky, P.V., L.I. Romanova, M.S. Kolesnikova, M.V. Bardina, E.V. Khitrina, S.V. Hato, F.J.M. Kuppeveld and V.I. Agol. 2009. Interactions between viral and prokaryotic pathogens in a mixed infection with cardiovirus and mycoplasma. Journal of Virology, 83: 9940-9951. 
15. Maia, I.G., A.-L. Haenniand and F. Bernardi. 1996. Potyviral HC-Pro: a multifunctional protein. Journal of General Virology, 77: 1335-1341.

16. Makkouk, K.M. and S.G. Kumari. 1996. Detection of ten viruses by the tissue-blot immunoassay (TBIA). Arab Journal of Plant Protection, 14: 3-9.

17. Makkouk, K.M., L. Bos, O.I. Azzam, S. Kumari and A. Rizkallah. 1988. Survey of viruses affecting faba bean in six Arab countries. Arab Journal of Plant Protection, 6: 53-61.

18. Makkouk, K.M., S. Kumari, A. Sarker and W. Erskine. 2001. Registration of six lentil germplasm lines with combined resistance to viruses. Crop Science, 41: 931-932.

19. McKirdy, S.J., R.A.C. Jones, L.J. Latham and B.A. Coutts. 2000. Bean yellow mosaic potyvirus infection of alternative annual pasture, forage and cool season crop legumes: Susceptibility, sensitivity and seed transmission. Australian Journal of Agricultural Research, 51: 325-345.

20. Murphy, J.F. and K.L. Bowen. 2006. Synergistic disease in pepper caused by the mixed infection of Cucumber mosaic virus and Pepper mottle virus. Phytopathology, 96: 240-247.

21. Pio-Ribeiro, G., S.D. Wyatt and C.W. Kuhn. 1978. Cowpea stunt: a disease caused by the synergistic interaction of two viruses. Phytopathology, 68: 12601265.

22. Pirone, T.P. and S. Blanc. 1996. Helper-dependent vector transmission of plant viruses. Annual Review of Phytopathology, 34: 227-247.

23. Poolpol, P. and T. Inouye. 1986. Enhancement of cucumber mosaic virus multiplication by zucchini

Received: May 10, 2017; Accepted: October 4, 2017 yellow mosaic virus in double infected cucumber plants. Annals of the Phytopathology Society of Japan, 52: 22-30.

24. Rentería-Canett, I., B. Xoconostle-Cázares, R. Ruiz-Medrano and R.F. Rivera- Bustamante. 2011. Geminivirus mixed infection on pepper plants: synergistic interaction between PHYVV and PepGMV. Virology Journal, 8: 104.

25. Rochow, W.F. 1972. The role of mixed infections in the transmission of plant viruses by aphids. Annual Review of Phytopathology, 10: 101-125.

26. Schwinghamer, M.W. and R.C. Larsen. 2011. Viruses reported to infect chickpea and/or lentil naturally. Table 5.In: Compendium of chickpea and lentil diseases and pests. W. Chen, H.C. Sharma and F.J. Muehlbauer (eds). APS Press, St. Paul, MN, USA, 73-76.

27. Syller, J. 2006. The roles and mechanisms of helper component proteins encoded by potyviruses and caulimoviruses. Physiological and Molecular Plant Pathology, 67: 119-130.

28. Vance, V.B., P.H. Berger, J.C. Carrington, A.G. Hunt and X.M. Shi. 1995. 5 proximal potyviral sequences mediate potato $\mathrm{X}$ potyviral synergistic disease in transgenic tobacco. Virology, 206: 583-590.

29. Wintermantel, W.M. 2005. Co-infection of Beet mosaic virus with beet yellowing viruses leads to increased symptom expression on sugar beet. Plant Disease, 89: 325-331.

30. Zhang, X.-S., J. Holt and J. Colvin.2000. Mathematical models of hostplant infection by helperdependent virus complexes: Why are helper viruses always avirulent? Phytopathology, 90: 85-93.

تاريخ الاستلام: 2017/5/10؛ تاريخ الموافقة على النشر: 2017/10/4 